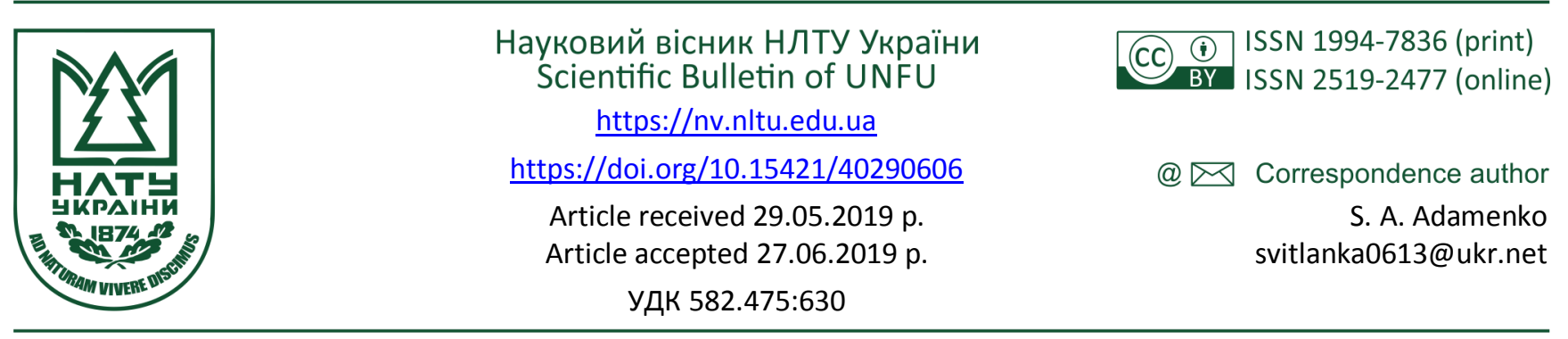

С. А. Адаменко

Уманський національний університет садівництва, м. Умань, Україна

\title{
ІНВЕНТАРИЗАЦІЯ ТА ОЦІНЮВАННЯ СТАНУ НАСАДЖЕНЬ СКВЕРУ БІЛЯ ОБЕЛІСКУ СЛАВИ В СЕЛІ МЕЖИРІЧКА
}

Досліджено видовий склад дендрофлори скверу обеліску Слави в с. Межирічка Голованівського району Кіровоградської області. Виявлено, що на території парку зростає 34 екземпляри хвойних і листяних деревних порід. Переважно це Асег пеgundo L. та Robinia pseudoacacia L., інші листяні перебувають у меншій кількості. 3 хвойних порід присутні Pinus nigra Arn. та Picea abies L. Оцінено відповідність вимог дерев до екологічних умов території скверу. Згідно з результатами дослідження, усі екземпляри належать до ослаблених дерев та за шкалою Л. П. Рисіна отримують оцінку 1. За відношенням до вмісту поживних елементів у грунті найчисельнішою є група мезотрофів. Відносно вибагливості рослин до освітлення, за С. С. П'ятницьким, найбільшу групу складають світлолюбні (малотіньовитривалі) - 50 \%. Обстеження насаджень на наявність ураження хворобами та шкідниками показало, що їхніх відсоток знаходиться в межах 35 \%. Найбільше уражень хворобами мали такі деревні породи, як T. cordata та J. regia. Найпоширенішими серед комах є мінуюча міль та гусінь кукурудзяного (стеблового) метелика. 3 оцінки життєздатності деревних насаджень скверу для встановлення відповідності умовам зростання видно, що 73,5 \% від їх загальної кількості знаходяться в задовільному стані. Встановлено, що сквер перебуває у відносно задовільному стані. Для покращання його декоративних якостей і повноцінного виконання ними всіх передбачуваних функцій надано відповідні рекомендації.

Ключові слова: дендрофлора; видовий склад; екологічні умови; ураження шкідниками і хворобами.

Вступ. За своїм цільовим призначенням сквери функціонують як місця короткочасного відпочинку людей і відіграють важливу декоративну роль, прикрашаючи і доповнюючи різні архітектурні ансамблі. Деревні та чагарникові насадження на територіях скверів надають індивідуальні, своєрідні риси об'єкту, сприяють покращенню мікроклімату та санітарно-гігієнічних умов (Marchenko \& Oleshko, 2011; Ivanchenko \& Bessonova, 2014). Тому необхідно ретельно підбирати їхній склад, враховуючи всі грунтово-кліматичні особливості місцевості та рівень рекреаційного навантаження. Докладніше обстеження стану окремих зелених насаджень $є$ актуальним завданням як 3 наукового, так і $з$ практичного поглядів, що дає змогу розробляти подальші рекомендації відносно покращення асортименту рослин, декоративності та функціонального навантаження об'єктів садово-паркового будівництва. Комплексний і грамотний догляд забезпечує деревним рослинам високу декоративність, стійкість до несприятливих впливів та рекреаційних навантажень (Dudin, 2003; Marno-Kutsa, 2012).

Мета дослідження - визначити таксономічний склад дендрофлори скверу та оцінити відповідність вимог деревних рослин до екологічних умов, що склалися на його території.

Об'єкт дослідження - сучасний стан декоративних насаджень скверу біля обеліску Слави в с. Межирічка.

Методи дослідження. Інвентаризацію насаджень здійснювали згідно $з$ документом (Instrukcia, 2001). Са- нітарний стан насаджень визначали за шкалою Л. П. Рисіна (2008): 0 - здорові дерева, 1 - ослаблені, 2 - сильно ослаблені, 3 - всихаючі, 4 - свіжосухостійні, 5 - старосухостійні, 6 - свіжовітровальні, 7 - старовітровальні, 8 - свіжобуреломні, 9 - старобуреломні. Розподіл рослин за екологічними шкалами проводили за О. Л. Бельгардом (1971) та П. С. Погребняком (1963).

Результати дослідження та їх обговорення. Село Межирічка засноване приблизно на початку XVII ст. (перша письмова згадка належить 1763 р.) (Yatran, 2019). Вагомий внесок у розвиток села зробив контр-адмірал та політичний діяч Олексій Михайлович Абаза, який отримав тут у володіння маєток, разом зі спиртзаводом, від нерідного батька графа Бобринського (Zruchno. Travel, 2019). До 1917 р. садиба в Межирічці належала сім'ї Абази. Наприкінці 1916 р. частину маєтку Абаза здав в оренду поміщику Глинці, а сам доживав віку у житловому дворику (Encyclopedia, 2019; Our-travels, 2019). У січні 1917 р. Олексій Михайлович тяжко захворів, а в лютому того ж року помер. Згодом розорили і маєток (Kirovograd region, 2019; IGotoWorld, 2019).

Сьогодні від садиби залишились руїни, які місцева влада не планує реконструювати. Неподалік цих руїн у радянські часи було створено обеліск Слави на честь воїнів-земляків, які віддали життя за Батьківщину. Через декілька років після закладання обеліску, для естетичного оформлення, навколо нього поступово почали

Інформація про авторів:

Адаменко Світлана Анатоліївна, канд. біол. наук, викладач, кафедра лісового господарства. Email: svitlanka0613@ukr.net Цитування за ДСтУ: Адаменко С. А. Інвентаризація та оцінювання стану насаджень скверу біля обеліску слави в селі Межирічка. Науковий вісник НЛТУ України. 2019, т. 29, № 6. С. 32-35.

Citation APA: Adamenko, S. A. (2019). Inventory and evaluation of tree plantations of the square near the obelisk of glory in village Mezhyrichka. Scientific Bulletin of UNFU, 29(6), 32-35. https://doi.org/10.15421/40290606 
висаджувати різні деревні породи, формуючи невеликий сквер (рис. 1).

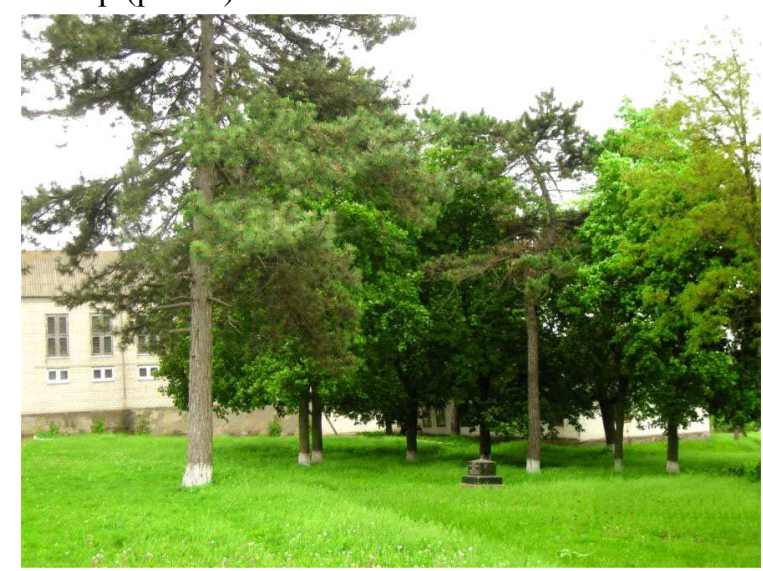

Рис. 1. Деревні насадження скверу

На території скверу відсутні спеціальні паркові газони, дерева висаджені в довільному порядку. Трав'яний покрив представлений синантропною рослинністю, бур'янами, нестійкою дерниною. За результатами інвентаризації зелених насаджень на території скверу було визначено 9 видів дерев, 3 яких 2 хвойні (P. nigra та $P$. abies) (таблиця).

Згідно з даними таблиці, усі екземпляри скверу належать до ослаблених дерев та за шкалою Л. П. Рисіна (2008) отримують оцінку 1. Для збереження декоративності насаджень та виконання ними санітарно-гігієнічних функцій важливо оцінити відповідність вимог дерев, що зростають у сквері, до певних екологічних умов (Ivanchenko, 2013). За відношенням до вмісту поживних елементів у грунті найчисельнішими є рослини, які належать до групи мезотрофів (рис. 2).

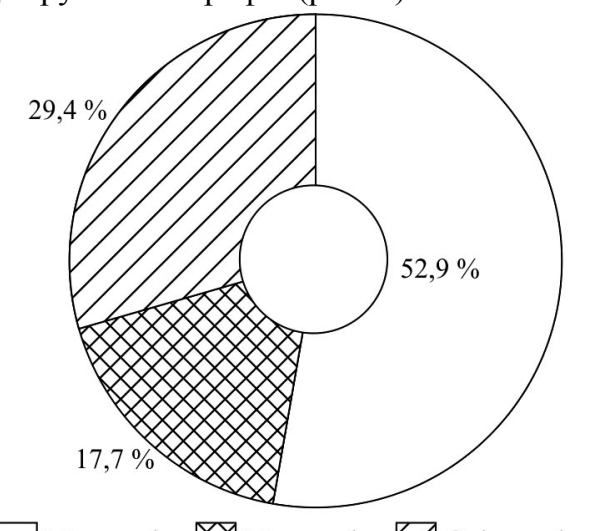

Рис. 2. Розподіл деревних порід за відношенням до родючості грунту, \% від загальної кількості екземплярів

Їхня кількість дорівнює 52,9 \%. Це P. abies, A. hipocastanum, T. cordata, A. negundo. Другою за чисельністю є група оліготрофів (29,4\%) (P. nigra i R. pseudoacacia). Інші види складають групу мегатрофів (А. saccharum, $F$. excelsior, J. regia). Відносно вибагливості до освітлення за С. С. П'ятницьким (1960) дерева розділяються на чотири групи: 1) дуже світлолюбні; 2) світлолюбні, малотіньовитривалі; 3) відносно тіньовитривалі; 4) дуже тіньовитривалі. За аналізом даних інвентаризації, до першої категорії належать тільки $R$. pseudoacacia, що становить 17,7\% від загального числа екземплярів скверу (рис. 3).

Таблиця. Біометричні показники та санітарний стан дерев

\begin{tabular}{|c|c|c|c|c|}
\hline \multirow{2}{*}{ Назва виду } & \multirow{2}{*}{$\begin{array}{c}\text { Висота, } \\
\text { м }\end{array}$} & \multicolumn{2}{|c|}{ Діаметр } & \multirow{2}{*}{ Стан } \\
\hline & & стовбур, см & крона, м & \\
\hline \multirow{4}{*}{ Pinus nigra Arn. } & 9 & 36 & 5 & \multirow{4}{*}{$\begin{array}{l}\text { Крона плоска, нещільна, у двох екземплярів наявна велика кількість } \\
\text { сухих скелетних гілок. Генеративний ярус середньорозвинений. }\end{array}$} \\
\hline & 8 & 36 & 4 & \\
\hline & 10 & 40 & 4 & \\
\hline & 8 & 36 & 6 & \\
\hline \multirow{2}{*}{ Picea abies L. } & 11 & 29 & 4 & \multirow{2}{*}{$\begin{array}{l}\text { Крона конічна, нещільна, але сухі гілки майже відсутні. Генератив- } \\
\text { ний ярус розвинений добре. }\end{array}$} \\
\hline & 12 & 31 & 4 & \\
\hline \multirow{5}{*}{$\begin{array}{c}\text { Aesculus } \\
\text { hipocastanum L. }\end{array}$} & 9 & 18 & 7 & \multirow{5}{*}{$\begin{array}{l}\text { Крона густа з товстим гіллям, округла. Сухі гілки майже відсутні. } \\
\text { Загалом стійкий до ураження комахами, але листя сильно пошко- } \\
\text { джене каштановою мінуючою міллю. Це призводить до передчасно- } \\
\text { го побуріння і опадання листя, що істотно зменшує декоративність. }\end{array}$} \\
\hline & 8 & 16 & 7 & \\
\hline & 8 & 16 & 6 & \\
\hline & 10 & 19 & 8 & \\
\hline & 9 & 16 & 7 & \\
\hline \multirow{4}{*}{ Tilia cordata Mill. } & 11 & 30 & 6 & \multirow{4}{*}{$\begin{array}{l}\text { Крона густа, розлога. Сухі скелетні гілки майже відсутні. Генера- } \\
\text { тивний ярус розвинений досить добре. }\end{array}$} \\
\hline & 13 & 27 & 7 & \\
\hline & 12 & 26 & 7 & \\
\hline & 11 & 25 & 6 & \\
\hline \multirow{7}{*}{ Acer negundo L. } & 11 & 23 & 6 & \multirow{7}{*}{$\begin{array}{l}\text { Крона рідка, широка. В екземплярів старшого віку дещо нерівномір- } \\
\text { на, наявні сухі скелетні гілки. Генеративний ярус розвинений добре. } \\
\text { Біля старших особин відзначено значну кількість порослі. }\end{array}$} \\
\hline & 10 & 21 & 6 & \\
\hline & 10 & 22 & 6 & \\
\hline & 6 & 19 & 4 & \\
\hline & 8 & 20 & 5 & \\
\hline & 6 & 18 & 4 & \\
\hline & 6 & 18 & 5 & \\
\hline \multirow{3}{*}{ Acer saccharum L. } & 10 & 31 & 6 & \multirow{3}{*}{$\begin{array}{l}\text { Крона густа, овальна. Наявна невелика кількість сухих гілок. Гене- } \\
\text { ративний стан розвинений добре. Стовбур місцями пошкоджений } \\
\text { комахами. }\end{array}$} \\
\hline & 10 & 30 & 6 & \\
\hline & 9 & 27 & 5 & \\
\hline \multirow{2}{*}{ Fraxins excelsior L. } & 15 & 18 & 7 & \multirow{2}{*}{$\begin{array}{l}\text { Крона рідка, ажурна. Присутні сухі скелетні гілки. Генеративний } \\
\text { ярус розвинений добре. }\end{array}$} \\
\hline & 15 & 16 & 7 & \\
\hline Juglans regia L. & 10 & 25 & 8 & $\begin{array}{l}\text { Крона кулеподібна, розлога, наявна невелика кількість сухих ске- } \\
\text { летних гілок, через пошкодження морозами. Генеративний ярус роз- } \\
\text { винений слабо. }\end{array}$ \\
\hline \multirow{6}{*}{$\begin{array}{l}\text { Robinia } \\
\text { pseudoacacia } \mathrm{L} .\end{array}$} & 11 & 25 & 7 & \multirow{6}{*}{$\begin{array}{l}\text { Крона розлога, рідка. Щільна тільки в молодших екземплярів. При- } \\
\text { сутні сухі скелетні гілки. Генеративний ярус розвинений добре. } \\
\text { Пошкоджень шкідниками не виявлено. }\end{array}$} \\
\hline & 11 & 26 & 7 & \\
\hline & 10 & 25 & 6 & \\
\hline & 8 & 20 & 5 & \\
\hline & 9 & 21 & 6 & \\
\hline & 9 & 21 & 6 & \\
\hline
\end{tabular}




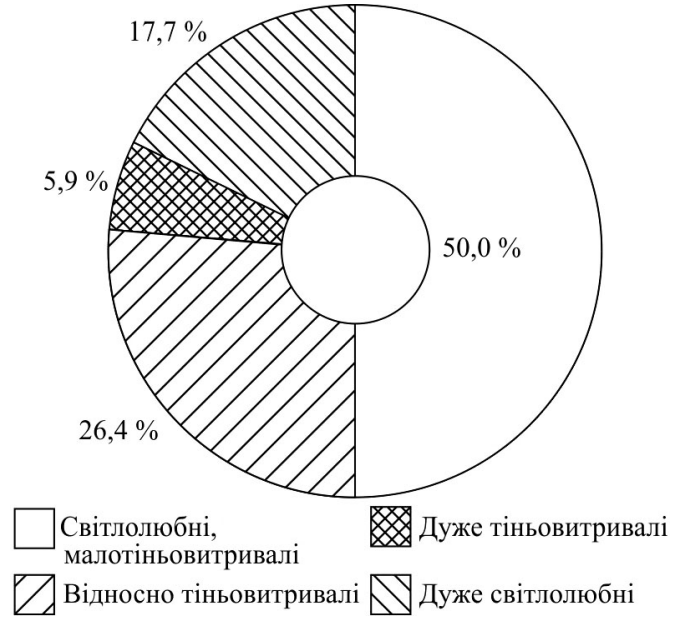

Рис. 3. Розподіл деревних порід за відношенням до освітленості, \% від загальної кількості екземплярів

До групи світлолюбних (малотіньовитривалих), що переважають у сквері, належать $P$. nigra, A. hipocastanum, A. negundo, J. regia, кількість яких становить $50 \%$, до відносно тіньовитривалих - T. cordata, A. saccharum, F. excelsior (24,4\%), до дуже тіньовитривалих тільки один вид - P. abies (5,9\%).

Обстеження насаджень на наявність ураження хворобами та шкідниками показало, що їхній відсоток знаходиться в межах $35 \%$. При цьому хвойні види майже не мали ознак пошкоджень. Серед листяних деревних порід поширеними хворобами були окремі види плямистостей, а також пошкодження трутовиком звичайним. Найбільше уражень хворобами мали такі деревні породи, як T. cordata та J. regia.

Найпоширенішою серед комах $є$ мінуюча міль, яка поїдає листя A. Hipocastanum, та гусінь кукурудзяного (стеблового) метелика, що завдає значної шкоди молодим пагонам і листю $A$. negundo. Окрім цього, більшість дерев скверу мають ознаки механічного пошкодження: морозобоїнами; гілками, обламаними вітровалами; дуплами та отворами, що утворені комахами та птахами; необроблені зрізи після рубань тощо.

Для встановлення відповідності умовам зростання було здійснено оцінку життездатності деревних насаджень скверу за шкалою (Tarabrin et al., 1986), при цьому акцент було зроблено на такі показники, як: густина крони, забарвлення листків (або хвої), наявність хвороб та пошкоджень (рис. 4).

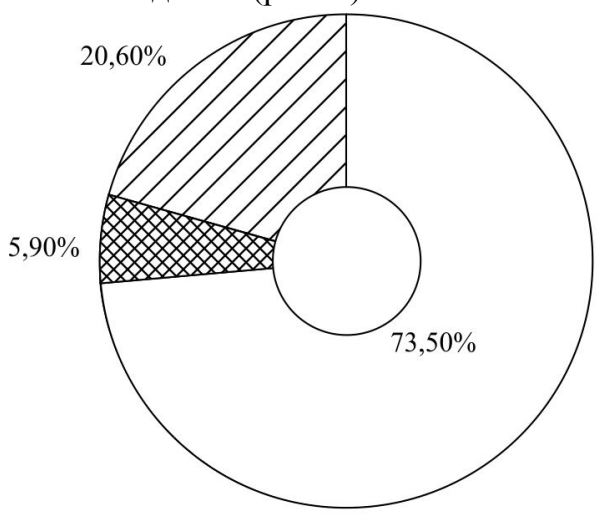

Задовільний Незадовільний Д Добрий

Рис. 4. Розподіл деревних насаджень за життєздатністю (\%)

Найбільша кількість дерев перебуває в задовільному стані (25 екз.), що дорівнює 73,5 \% від їх загальної кількості. У доброму стані перебувають декілька молодих екземплярів акації і клена, у яких відсутні сухі скелетні гілки. У незадовільному стані перебуває два екземпляри $P$. nigra $(5,9 \%)$, що ростуть біля входу в сквер (рис. 5).

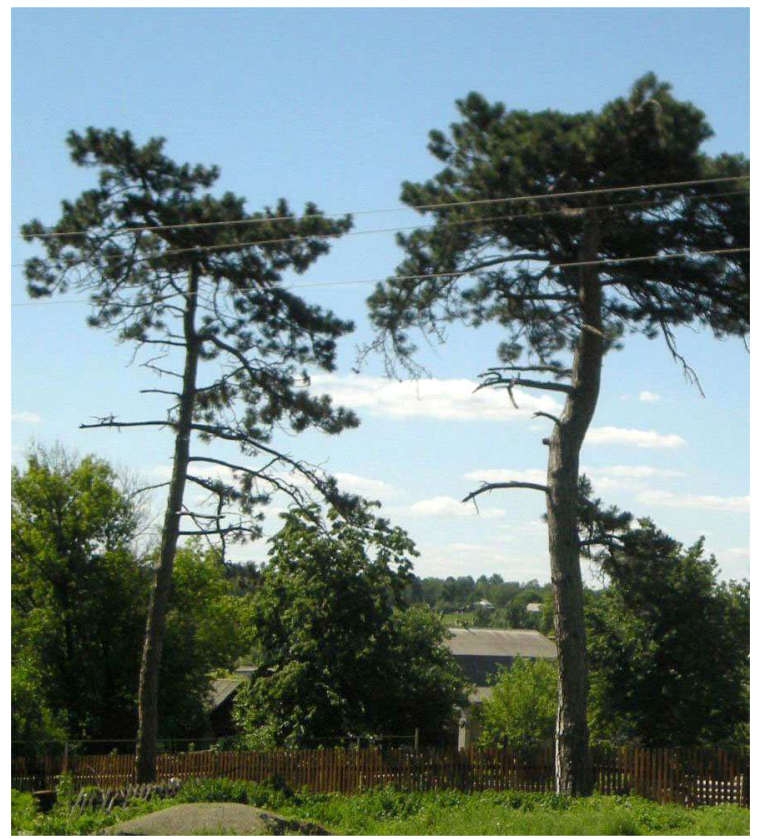

Рис. 5. Екземпляри $P$. nigra, що знаходяться в незадовільному стані

Ці дерева мають невелику рідку крону та багато сухих скелетних гілок. Плодоношення присутнє, однак насіння у шишках майже немає або воно нежиттєздатне. Це можна пояснити сильним ущільненням грунту внаслідок складання під ними частини будівельних матеріалів.

Висновки. Отже, сквер у с. Межирічка перебуває у відносно задовільному стані. Однак для покращання його декоративних якостей необхідні реконструктивні заходи, спрямовані на відновлення складу насаджень та елементів благоустрою, а саме:

1. Створити оптимальні умови для росту та розвитку всіх деревних порід, сприяти їх природному поновленню. Цього можна досягти регулярним вживанням відповідних агротехнічних заходів (скошування високої трави, вирубування малоцінних чагарників, удобрення грунту та ін.).

2. Приділити увагу лікуванню хворих дерев, уражених ентомошкідниками та фітозахворюваннями. 3 метою відновлення старих екземплярів, сильно уражених хворобами і шкідниками, необхідно висаджувати молоді дерева методом піднаметових культур. Це забезпечить вчасну зміну насадженням перестійного віку, що в будь-який момент можуть загинути.

3. Приділити більшу увагу хвойним породам, покращуючи умови ї росту та розширюючи ї асортимент. Наприклад, вздовж забору, що огороджує сквер, можна висадити кущі Juniperus sabina L., а в його центрі, навколо самого обеліску - декілька декоративних форм роду Thuja L. Це допоможе скверу зберігати охайний $\mathrm{i}$ привабливий вигляд у будь-яку пору року.

\section{Перелік використаних джерел}

Belgard, A. L. (1971). Stepnoe lesovedenie. Moscow: Lesnaya promyshlenost, $336 \mathrm{p}$. [In Russian].

Dudin, R. B. (2003). Stan nasadzhen Striyskogo parku m. Lvova ta problem yogo rekonstruktsii. Scientific Bulletin of UNFU, 13(5), 85-89. [In Ukrainian]. 
Encyclopedia. (2019). Encyclopedia of modern Ukraine. Retrieved from: http://esu.com.ua/search articles.php?id=25293. [In Ukrainian].

IGotoWorld. (2019). Ruiny sadyby kontr-admirala Abazy, Mezhyrichka. Retrieved from: https://ua.igotoworld.com/ua/poi object/101277 ruiny-abazy-mezhirechka.htm. [In Ukrainian].

Instruktsiya. (2001). Instruktsiya $\mathrm{z}$ tehnichnoi inventaryzatsii zelenyh nasadzhen u mistah i selyschah miskogo typu Ukrainy. Zatverdzhena Derzhavnym komitetom budivnytstva, arhitektury ta zhytlovoi polityky № 226 vid 24.12.2001 r. [In Ukrainian].

Ivanchenko, O. E. (2013). Inventaryzatsiya ta otsinka stanu derevnyh nasadzhen parku im. Kalinina m. Dnipropetrovsk. Pytannya bioindykatsii ta ekologii, 18(2), 211-226. [In Ukrainian].

Ivanchenko, O., E., \& Bessonova, V. P. (2014). Vydoviy sklad ta stan derevnyh nasadzhen parku "Voinam-vyzvolytelyam" m. Dnipropetrovsk. Scientific Bulletin of UNFU, 24(4), 22-27. [In Ukrainian].

Kirovograd region. (2019). Mezhyrichka. Retrieved from: http://kirovograd-info.com/mista-i-sela-kirovogradskoi-oblasti/golovanivskyi-rajon/mezhyrichka-.html. [In Ukrainian].

Marchenko, A. B., \& Oleshko, O. G. (2011). Analiz sychasnogo stanu zelenyh nasadzhen skveru bilya torgovyh ryadiv $\mathrm{m}$. Bila Tserkva. Agrobiology: collection of scientific works of BNAU, 6(86), 131134. [In Ukrainian].
Marno-Kutsa, O. Y. (2012). Suchasny stan zelenyh nasadzhen skveru im. T. G. Shevchenka v m. Uman. Scientific Bulletin of UNFU, 22(11), 102-108. [In Ukrainian].

Our-travels. (2019). Sela i poselki Golovanevskogo raiona. Retrieved from: https:/our-travels.info/ost/Goroda/Ukraine/Kirovograd/Golovanevsk-ns.php. [In Russian].

Pogrebnyak, P. S. (1963). Obschee lesovodstvo. Moscow: Selhozgiz, 250 p. [In Russian].

Pyatnitskiy, S. S. (1960). Kurs dendrologii. Kharkiv: Publishing House HDU, 420 p. [In Russian].

Rysin, L. P. (2008). Rekreatsyonnoe lesopolzovanie - sovremennaya situatsiya i perspektivy. Statsionarnye issledovaniya vliyaniya rekreatsii na lesnye biogeotsenozy, (pp. 5-39). In-t lesovedeniya RAN. Tula: Grif i K. [In Russian].

Tarabrin, N. P. et al. (1986). Fitotoksichnost $5^{*}$ organicheskih i nejrganicheskih zagryazniteley. Kyiv: Scientific thought, 216 p. [In Russian].

Yatran. (2019). Retrieved from: http://www.yatran.com.ua/articles $/ 435 . \mathrm{html}$

Zruchno. Travel. (2019). Vash pomichnyk dlia zruchnoho vidpochynku. Retrieved from: https://zruchno.travel/ObjectEntity/ObjectEntity? idCrm=f3637a97-43c7-29eb-6428-58b0137f439c \& lang=ru. [In Ukrainian].

S. A. Adamenko

Uman National University of Horticulture, Uman, Ukraine

\title{
INVENTORY AND EVALUATION OF TREE PLANTATIONS OF THE SQUARE NEAR THE OBELISK OF GLORY IN VILLAGE MEZHYRICHKA
}

\begin{abstract}
A detailed survey of the state of individual green plantations is an actual task both from the scientific and practical view, which allows us to develop further recommendations regarding the improvement of the range of plants, decorative and functional load of the objects of garden and park construction. Inventory of plantings is carried out in accordance with the document (Instrukcia..., 2001). The sanitary condition of plantations is determined by the scale of Rysin (2008). The distribution of plants according to ecological scales is carried out by Belhard (1971) and Pogrebnyak (1963). According to the results of the study, all specimens of the park are defined to belong to weakened trees and receive a mark of 1 by the scale of Rysin (2008). The mesotrophic group is the most numerous by relevance of the content of nutrients in the soil. Concerning the trees demand for light by Pyatnitsky (1960), the largest group is heliophilous plants $-50 \%$. Inspection of plantings for the presence of diseases and pests has shown that their percentage is within $35 \%$. In this case, the coniferous species almost had no signs of damage. Among the deciduous tree species, common types of spots were widespread diseases, as well as the damage of the tinder fungus. The most affected by diseases were such tree species as $T$. cordata and J. regia. The most widespread insects are the horse-chestnut leaf miner and the European corn borer. An assessment of the viability of the trees of the square to establish compliance with the conditions of growth showed that $73.5 \%$ of their total number are in satisfactory condition. Summing up, it can be noted that the square in the village Mezhyrichka is in a relatively satisfactory condition. However, to improve the decorative qualities of the square, it is necessary to create optimal conditions for the growth and development of all wood species, and to promote their natural renewal. This can be achieved by regular taking of appropriate corresponding agrotechnical measures (mowing of high grass, cutting of low value shrubs, fertilizing of the soil, etc.). In order to restore old specimens that are heavily affected by diseases and pests, it is necessary to plant young trees by the method of under canopy cultures. This will ensure a timely change in the planting of persistent age that can be lost at any time. It is also necessary to pay more attention to coniferous species, improving the conditions for their growth and expanding their assortment.
\end{abstract}

Keywords: dendrology; species composition; ecological conditions; pests and diseases. 